Relations industrielles

Industrial Relations

\title{
Eileen Boris, Home to Work: Motherhood and Politics of Industrial Homework in the United States
}

\section{Izik Urla Zeytinoglu}

Volume 50, numéro 2, 1995

URI : https://id.erudit.org/iderudit/051027ar

DOI : https://doi.org/10.7202/051027ar

Aller au sommaire du numéro

Éditeur(s)

Département des relations industrielles de l'Université Laval

ISSN

0034-379X (imprimé)

1703-8138 (numérique)

Découvrir la revue

Citer ce compte rendu

Zeytinoglu, I. U. (1995). Compte rendu de [Eileen Boris, Home to Work:

Motherhood and Politics of Industrial Homework in the United States]. Relations industrielles / Industrial Relations, 50(2), 461-463.

https://doi.org/10.7202/051027ar

Tous droits réservés @ Département des relations industrielles de l'Université Laval, 1995
Ce document est protégé par la loi sur le droit d'auteur. L’utilisation des services d'Érudit (y compris la reproduction) est assujettie à sa politique d'utilisation que vous pouvez consulter en ligne.

https://apropos.erudit.org/fr/usagers/politique-dutilisation/ 
construction sociale des marchés du travail et des rapports sociaux de l'emploi, à partir desquels s'organisent les clivages sociaux dans l'entreprise.

Les questions soulevées suite aux nombreux changements dans le travail et l'emploi méritaient certainement qu'un volume y soit consacré. La démarche choisie par les auteurs consiste en un traitement analytique à l'aide de plans dualistes : tracer un bilan factuel et intellectuel, traiter des métamorphoses du travail et de l'emploi, s'appuyer sur les travaux en sociologie et en économie du travail. Avec un tel projet, les auteurs sont forcément obligés de tracer à grand trait leur argumentation. Les parties sur les nouvelles avenues de recherche et sur les nouveaux développements théoriques souffrent le plus de ces ellipses intellectuelles. Néanmoins il s'agit d'un ouvrage important pour le traitement original de l'ensemble de ces questions autour des notions de convention, d'interaction et de négociation. La lecture est agréable, certains chapitres sont fort relevés et une bibliographie substantielle supplée aux lacunes de la démonstration. Quiconque s'intéresse à ces questions devrait lire ce volume.

DENIS HARRISSON

Université du Québec à Hull

\section{Home to Work: Motherhood and Politics of Industrial Homework in the United States}

by Eileen BORIS, Cambridge, UK, Cambridge University Press, 1994, 383 p., ISBN 0-521-44370-9.

This book is an historical overview of waged (industrial) labour in the U.S An interesting aspect of the book is that it connects homework of 1880 s to the present day homework of white-collar female employment. It shows the similarities of working at home as waged labour then and now, and weaves this within a feminist framework.

The book presents the view that workplaces have been organized without considering the parental identity of workers. The workplace assumes that most workers are men with a supporting woman at home. In her book, Boris combines feminist theory and historical research to address the "double day" of working women, how "home" and "work" interconnect despite their ideological separation. The book also shows how 1980s deregulation of homework in the U.S. brought past and present together.

The author's purpose in this book is not to give a precise economic or social history. Her purpose is to discuss the social construction of concepts of wom- anhood and manhood, visions of proper homelife and childhood, and how the state policy separated home from work. The book is illustrating the historical construction of gender and the gendering by giving examples of the state and its actions through legislation and regulation.

Boris shows in her book that we have "the history of labor law and the history of protective labor legislation for women and children, but the gendered assumptions of the former remain unrevealed in major studies" (p. 7). The book fulfills its purpose by examining how, in the U.S. context, policies such as women's labour laws and maternal health care had gendered assumptions; and how middle- and upper-class white women's culture, through their organizations, influenced state politics creating the belief in female difference. Starting in late nineteenth century the concept of difference assigned women superior moral and personal qualities, such as nurturing, cooperativeness and selflessness; giving women the major responsibility of 
household work and child rearing. Later on, this view was blended into today's concept of "double day" or "double burden". These women, then and now, sought equality not on the basis of what was normal for men, but in terms of what they generalized as women's life experiences, often conflating women with mother. Boris' book also shows that such policies often conflicted with the needs and interests of lower-class women of mostly new immigrants of different races.

By focusing on the "difference", Boris' book shows that women were perceived as both dependent and powerful by virtue of their status as mothers, and the industrial homework exposed its contrary meanings. Women of lower economic class working at home also viewed themselves different from men; they agreed that mothers should stay home, but rather than destroying the family life, homework was the best alternative.

In her book Boris gives examples of how "motherhood and difference empowered as well as subordinated, opened spaces as well as restricted, served strategic as well as ideological ends" (p. 9). The book is divided into four parts focusing on representative points in the emergence of homework as a social and political concern. The first part focuses on how men's freedom to contract ignored women's necessity to work as paid labour at home. The chapters in this section give examples of how craft unions of nineteenth century crusaded against homework and thought regulating it would end its attractiveness for employers. These chapters show the disunity within working class; particularly male trade unionists working to abolish homework seeing it as an assault on their masculinity and status as citizens. There are good examples in the book showing men, no matter of their class, agreed that women's place was at home. Garment industry is a perfect example of that time. In the book women (of upper- and middle- class) joining forces with men, to regulate and ultimately eliminate homework is explained vividly. The book also shows how this is done at the expense of lower-class women.

Part two covers the time period from World War I to the New Deal, followed by part three focusing on the development of labour standards. These sections should be of particular interest to labour historians, presenting how discourses of patriotism and citizenship enter into homework debate and how war efforts influence the state view of what is acceptable in working conditions.

In the last part, the author discusses the development of the white-collar homebased work from the late 1940 s to the 1980 s. It presents how in 1980 s and 1990s, homework defenders speak of women's rights in terms similar to 1920 s; how homework (now using new computer technologies) appears as a solution to the work and caring of family dilemma of the present day. This section also argues that homework is not a solution to childcare; and how the policy makers, employers and women themselves have to confront the underlying reasons of why women are homeworkers. Policymakers often forget that homeworkers are working mothers who need social support and week empowerment from the paid work.

I highly recommend this book to a wide range of audiences: academicians and laypersons with interest in industrial relations, policy-makers, feminists and everyone interested in women and work issues. The book opens up horizons, makes one rethink the gendered framework of social and labour legislation, employer and union policies, men's and women's actions and views. For some of us who already know these issues and agree with Boris' views, the book is an invaluable source giving examples from the history of U.S. labour movement. In conclusion, I would like to 
reiterate that " $[\mathrm{f}]$ amily and state, home and work, private and public are false dichotomies that sustain hierarchy....
Homework and its regulation illustrates this process" (p. 365).

IZIK URLA ZEYTIMOGLU Mc Master University

\section{Descartes' Error: Emotion, Reason, and the Human Brain}

by Antonio R. DAMASIO, New York, G.P. Putnam, 1994, 312 p., ISBN 0-39913894-3.

Des définitions inédites et des descriptions accessibles

Descartes' Error est un livre fascinant! Cet ouvrage contient des descriptions vulgarisées du cerveau humain, non pas strictement de son côté "matériel ", mais surtout de son côté "logiciel ". Antonio R. Damasio, le directeur du Département de neurologie au Collège de médecine de l'Université de l'lowa, a su décrire en des termes on ne peut plus clair: la création et le fonctionnement de l'esprit; l'émergence de la connaissance chez l'être humain; l'origine des émotions et des sentiments et leurs rôles; ce qu'est la rationalité, l'intuition, la subjectivité, etc. Qui plus est, ce livre contient des descriptions à la fois captivantes et révélatrices du raisonnement et de la prise de décisions chez l'humain. Quant à l'erreur attribuée à René Descartes, même si Damasio ne la révèle "officiellement " qu'à la fin, le lecteur la perçoit progressivement.

\section{La structure du livre}

L'ouvrage est composé de trois parties. La première est axée sur le cas de Phineas P. Gage, un responsable de chantier devenu célèbre au milieu du siècle passé. Lors de travaux de dynamitage, une longue barre de fer lui a " pénétré la joue gauche, percé la base crânienne, traversé l'avant du cerveau pour sortir à toute vitesse au sommet de sa tête ". Invraisemblablement, deux mois après ce terrible accident, il est jugé guéri. Mais que dire de son comportement? Par l'entremise de ce "vieux " cas (très bien documenté pour l'épo- que) et d'un autre plus récent, l'auteur énonce sa thèse qui relie certaines sections du cerveau aux processus de raisonnement et de prise de décisions.

La deuxième partie sert à clarifier cette mystérieuse alliance qui rapproche le cerveau et le corps. Ici, Damasio s'attarde sur l'importance de l'image, sa perception et son stockage, pour générer la pensée. Il décrit - sur le plan neurobiologique - ce que sont les émotions et les sentiments. Au dernier et très important chapitre de cette partie, le neurologue présente son hypothèse des marqueurs somatiques.

La dernière partie de Descartes' Error est une brève description de recherches, d'expériences, de tests que l'auteur a entrepris pour valider son hypothèse. Il y expose l'erreur de Descartes. Aussi, y ajoute-til un "post-scriptum " contenant une critique notable sur la neurobiologie et l'enseignement de la médecine. Il soutient que peu d'écoles de médecine offre une formation formelle sur l'esprit "normal", que le programme scolaire souffre d'un manque en matières de psychologie, de neuropsychologie et de sciences neurologiques.

Les éclaircissements que Damasio présente de plusieurs concepts et sa manière de définir certains termes facilitent grandement la "tournée " d'un monde étonnant.

\section{L'esprit et la pensée}

Esprit est un des mots autour duquel gravitent des thèmes marquants. Selon l'auteur, avoir un esprit signifie qu'un 